\title{
Forest Fringe Communities Participation in Forest Reserve Sustainability in Ghana
}

\author{
Charles Adusei ${ }^{*}$, Jasper Yao Dunyah ${ }^{2}$ \\ ${ }^{1}$ Department of Accounting, Finance and Banking, Faculty of Business Studies, Garden City University College, \\ Kumasi, Ghana \\ ${ }^{2}$ Forest Services Division of Forestry Commission, Atebubu Brong-Ahafo Region, Ghana \\ Email: *sircharly2002@gmail.com
}

Received 29 December 2015; accepted 12 January 2016; published 24 February 2016

Copyright (C) 2016 by authors and Scientific Research Publishing Inc.

This work is licensed under the Creative Commons Attribution International License (CC BY).

http://creativecommons.org/licenses/by/4.0/

(c) (i) Open Access

\section{Abstract}

The paper investigated the forest fringe community's participation in forest reserve sustainability in Ghana using Brong-Ahafo Region of Ghana as a case study. The key issues examined are the forest reserve management strategies, stakeholder's participation and livelihood activities of forest fringe communities. Two stage sampling technique was used to sample forty-two respondents for the study. A structured questionnaire in an interview form was used to solicit information from the respondents. Descriptive statistics was used to analyse the data. The results of the study indicate that there is a management plan for the forest reserve but Forest Services Division (FSD) does not follow its prescriptions strictly, the involvement of Forest Fringe Communities (FFCs) by FSD in the management of the forest reserve was insignificant and evidence of FSD not establishing income generating activity for FFCs livelihood sustenance. It is therefore recommended that community members should be empowered to play the role of co-managers of the forest reserve and there should be regular visit and interaction between FSD and the FFCs.

\section{Keywords}

Forest Reserves, Sustainability, Forest Fringe Communities, Ghana

\section{Introduction}

One of the key factors of Ghana's deforestation has been the alienation of forest fringe communities from policy formulation, planning and implementation of various forms of management strategies of the forest reserves that have been engaged so far although such communities were expected to assist in protecting the forests (Ministry

${ }^{*}$ Corresponding author. 
of Land and Forestry, 1996).

According to World Bank (2002), not less than 1 billion people depend on forests for their livelihoods at various degrees. And it is not surprising that the passive integration of community livelihood activities into sustainable forest management has encouraged illegal forest harvesting since local people depend directly or indirectly on the forest for survival. More so, the weakness in deterrent legal sanctions such as low fines imposed on the perpetuators of forest offenders does not deter people. It is therefore not surprising that for the period of 1990-2010, Ghana lost an average of 125,400 ha or $1.68 \%$ per year. In total, Ghana lost $33.7 \%$ or around 2,508,000 ha of its forest cover these periods (FAO, 2010).

Ghana as a developing country is an agrarian economy and depends heavily on agriculture for its development. The rate of deforestation which is characterized by unpredicted and heavy rain falls impacts negatively on the livelihoods of many farming/forest fringe communities and the nation as a whole. Many organizations are spreading their commitment to responsible business practices to their value chains, from subsidiaries to suppliers. Many of those organizations have taken the path of supply chain sustainability because of the numerous rewards it can deliver. Indeed, sustainable supply chain management can be a strong driver for value and success for business and the wellbeing of society.

More and better managed forest reserve is needed to meet the increasing global demand for food, feed, woodfuel and fibre. The continuous trend of land degradation in forest reserves coupled with increasingly competition for land and weak governance are threatening the functioning of the ecosystems at the forest reserve level, thus putting resources at risk. Sustainable forest reserve management is one of the major responses to meet that challenge.

The rate at which the forest is destroyed through bush fire and illegal logging, illegal small scale mining "galamsay" and chain sawing has implications on the effectiveness and efficient application of management strategies. However, forests contribute more significantly to the rural populace's income and quality of life. In order to continue serving these roles to humanity, forest reserve sustainability needs to adapt to realities of local needs and opportunities. Against this background, this study seeks to examine the recognition of Forest Fringe Communities' inputs and their livelihood sustenance in Tain 1 Forest Reserve in the Brong Ahafo Region of Ghana.

\subsection{Stakeholder Participation in Forest Reserve Management}

It is the wish and still the common concern of many and other environmentalist as to how to incorporate ideas and views of various stakeholders in the management of the forest and other resources. It has been widely accepted that participation of stakeholders especially of local people is a prerequisite for sustainable forest reserve management. However over the last decades the concept of "participation" has become the dominant drive in the international thinking on forest management and development as one of its conceptual pillars. It is also strongly observed by professional foresters and other environmentalist that Forest Fringe Communities greatly influence forests since they depend on the forests and their resources for most their livelihoods.

According to Blomley (2013), community forestry is an evolving subcategory of forestry under which communities or groups of people have partial to full rights over specific forests, including the rights to establish, implement, and enforce rules governing access and use of those forests. These rights may be formal legal rights, or traditional or customary rights. He went on to say that participatory forest management, community-based forest management or joint forest management can be considered to be types of community forestry if communities have rights to participate in significant decisions on how the forest is used or managed.

Community Forestry focuses on improving their livelihood and welfare of the rural people in conserving natural forest systems through local participation and cooperation. The principle of participation therefore demands that forest fringe communities are involved in all decisions concerning the management and development of their forest resources, since that will give them a better understanding and commitment to the natural resources development and protection by them (Kotey et al., 1998). It is on this ground that one would not be far from asking management to ensure that forest is at least, co-managed and maintained if not improved. The permissible yield therefore should correctly be ascertained so that over exploitation does not take precedence over conservation but rather forest reserve management should be geared towards conserving the resource for the sake of the future generations unborn and also for posterity.

According to Blomley et al. (2011) and Blomley and Franks (2009) Community Based Groups are known as vital stakeholders in Sustainable Forest Management. This management approach is more all-inclusive than 
conventional reductionist methods of forest management and planning and advocates the inclusion of all stakeholders in decision making. The Community Based Groups or forest fringe communities as earlier on mentioned in the previous paragraph therefore have strong influence on sustainable forest management and as such, acts and exclusions of these stakeholders have significant impacts. The involvement of Local Communities in forest resource management has seen the birth of a lot of Community Based Groups (CBG's) in Forest Resource Management (CFN, 2008; Blomley \& Ramadhani, 2006). emphasised on the fact that their presence brings to bare different knowledge and ideas that would make a strong basis for sustainable forest management achievable. Their roles and their impact on the development of the community cannot be under-estimated but with current emergence of these groups, there are doubts as to whether they are well structured and their roles being clearly defined in order to reduce any conflicts of interest that may occur (Sagoe, 2013).

It is so obvious that sustainable management of the forest cannot be achieved if the Community Based Groups are ignored as conflicts of interest often exist among the various interest groups. As the saying goes "when the last tree dies the last man dies", there has to be attitudinal change of all interest stakeholders or a proactive frame work for sustainable forest management by all parties, there will not be trees left to harvest, no more fuelwood, no more forest products and no more nature to attract tourist for promotion of ecotourism.

There is therefore the need to sustainably manage forest reserve so that it can be able to perform its basic functions. However, one should carefully diversify the management regime and outreach relative to the resource in question, taking the physical properties and status of the particular resource (forest) into consideration. For instance looking at the current status of our forest today as against the demands for its multiple uses there is the need to draw strict distinction between production forest, protection forest and conservation areas. In line with this, forest management greatly assists to distinguish an area from that of other areas so as to ensure that there is continuous flow of benefits for the society leading to sustainability. Furthermore, forest management ensures that correct records are kept so that experience does not go waste and control is maintained over the operation.

\subsection{The Concept of Participatory Management Approach}

Participation commonly refers to some aspect of involvement of local population in the design, implementation and evaluation of project. In short it simply means getting involved in an activity. To initiate such a management process, it is necessary to determine the primary stakeholders in the project-individuals and groups with a vested interest in the outcome of the project. Once the stakeholders have been identified, equitable partnerships must be established, so that all stakeholders feel comfortable with their roles in the project design process to empower the resource user groups and the rural organizations within which they are incorporated (Brown, 2000).

Therefore Local involvement in forest management occurs in diverse forms, but is broadly encompassed by the term "Participatory Forest Management" (PFM). The generic term "forests" is used to encompass diverse types, from dry woodlands to moist tropical forests, coastal mangroves and plantations. "Community" in the context of PFM refers to people living within or next to forests.

According to CFN (2008) while every community is arriving at more participatory approaches especially to natural forest management, broad commonalities among processes and paradigms are notable. Root causes of failures in twentieth-century forest management are relatively common, as are the forces now driving action. Prime among these is widening sociopolitical transformation on the continent towards more inclusive norms in the governance of society and its resources. More than any other new strategy in the forest sector, PFM embodies this emergent democratization. Recognition that forest management is itself primarily a matter of governance is crystallizing with technically driven functions reassuming their proper place as support functions to sound forest governance regimes.

The PFM in its initial developments inclined to involve the local people in the communities to participate where they were seen as users and their interest was access to forest land and getting some portion of the generated income from the forest resource. According to Wily \& Mbaya (2001) buffer zone developments were also flourishing, with the hope that this will help the communities to turn their eyes from the forest. It has emerged that forestry administrators have realized that local participation is more meaningful and effective as it made them to feel as owners in their own rights, this goes beyond cooperation to commitment to ensure forest sustainability.

It is now emerging in community forests the need for authorities to empower the local communities to play their role effectively in forest sustainability by backing it with bye-laws of the local authorities suggested 
(Asare, 2001). The eagerness of the state through the forestry commission to enable the local people to use classified or reserved land is not forthcoming as their words are not backed with timelines commitments. This is so since the state is not ready to entrust the communities over jurisdiction with significant resources. Lack of considerable roles of the community in critical decision-making to the use and control of the resources affect the local people in revenue sharing and to a large extent local licensing which seen as the basis of PFM.

Partnership in community forestry is gradually moving away from consultative and collaborative norms so to enable the communities to function as autonomous forest authorities to some extent. The local people within are looking beyond just access to the forest but to be seen as custodians which is critical to any agreements with the forestry authorities. One challenging issue is undefined local-level governance over forest. The drift is towards having the local community to be seen as more inclusive. According to Fomete (2001) it is essential for the state to institute a tougher legal framework to establish local community's roles in meaning jurisdiction. There is the greater need for the local forest managers to be accountable to the benefit of the wider communities since they are acting on their behalf.

Action to involve forest-local communities in the management of forests is well under way in Africa (Asare, 2000). Most of these developments have, or quickly acquire, policy and legal support through national forestry policies, national forest management plans and particularly the new forestry legislation already noted. In Ghana, two communities were assisted to declare Dedicated Forests (215 ha and 190 ha) in 1994, a development that has not yet been replicated. A Community Forestry Management Unit since 1992 promotes the creation of community forestry committees as a contact point for consultation in forest reserve planning. Boundary maintenance contracts are being issued to adjacent communities and the "taungya" regime has been modified to allow foresters to pay farmers who tend seedlings in planted areas. Again a new proposal for a revised "taungya" system, which would be self-financing and sustainable, was designed through as 18-month consultation process (July 2001 to December 2002) initiated by the Government of Ghana with support from FAO and the World Bank requires farmers and the Forestry Commission each to receive 40 percent of benefits accruing based on their inputs while landowners should receive 15 percent (i.e. traditional authorities, 7 percent and tribal land owners 8 percent) and forest adjacent communities should receive 5 percent (Agyeman et al., 2003).

Furthermore, there is also Ghana and Japanese government project between JICA-Japan/Forestry Commission-on Participatory Forest Resource Management Project acronyms PAFORM from 2004 to 2009 initiated a participatory approach to Forest Reserve Management. The approach is locally defined as a combination of two directions of participation: participation of communities in forest reserve management and participation of Administrations Forest Services Division (FSD) in the development of Income Generation livelihood Activities (IGA) of the communities. This approach is therefore to create a lasting relationship between FSD and the communities from a give-and-take point of view that can lead in establishing an amicable relationship so that the effort of FSD toward forest reserve management could be well cherished by the Forest Fringe Communities.

\section{Study Area and Methodology}

\subsection{The Study Area}

The Tain 1 Forest Reserve is situated in the Sunyani District. Tain 1 forms Forest Management Unit 00 (FMU 00 ). It lies between latitude $0^{\circ} 00^{\prime} \mathrm{W}$ and $0^{\circ} 00^{\prime} \mathrm{W}$; and between longitude $0^{\circ} 00^{\prime} \mathrm{N}$ and $0^{\circ} 00^{\prime} \mathrm{N}$. The Forest Reserve falls under the Sunyani East District Assembly politically. The study is however focused on few stakeholders in and around one forest reserve (Tain 1) in Sunyani Forest District in the Brong Ahafo Region but also keeping in mind the possible wider implications of the study for the other forest reserves and their respective stakeholders of the Forestry Commission of Ghana.

\subsection{Methodology}

This study adopted the exploratory design. Exploratory research is used when the topic or issue is new and when data is difficult to collect. The focus of exploratory design is on gaining insights and familiarity on social phenomena. A key limitation of exploratory design is that findings are not typically generalisable to the population at large. Exploratory research design is flexible and can address research questions of all types (what, why, how). Exploratory design can also utilize both qualitative and quantitative methods including in-depth interview and focus groups to gather data. In addition, the design helps determine the appropriate data collection methods and 
selection of respondents.

The study was conducted among all the relevant stakeholders within the Tain 1 Forest Reserve in Sunyani Forest District. These are the personnel from the Forest Service Division, District Assemblies, Traditional Authorities, Timber Contractors, Land owners and the Fringe Communities. Two stage sampling procedure was used to sample the respondents. At the first stage, purposive sampling procedure was used to choose Tain 1 Forest Reserve in Sunyani for the study. Second stage of the sampling process involved simple random sampling of various respondents for the study. Simple random sampling was used to select five (5) respondents each from these six (6) selected communities to make it thirty (30), however the additional twelve (12) respondents were recruited from the other stakeholder's group. Fortunately these communities had the opportunity to work with the second author under the PAFORM project from 2004 to 2009.

The data collection methods were in two phases. The first phase involved desktop literature search for secondary information and documentations on sustainability of forestry. The second phase constituted the field work, which employed questionnaires, interviews and stakeholder consultations to obtain first-hand information from relevant respondents. Descriptive statistics such as frequency tables and percentages were used to present the characteristics of the respondents with the help of Statistical Package for the Services Solution (SPSS).

\section{Results and Discussion}

\subsection{Socioeconomic Characteristics of the Respondents}

Table 1 describes the general characteristics of the respondents, among forty-two (42) respondents studied. The male representation was $(53.2 \%, \mathrm{n}=22)$ as compared to $(47.7 \%, \mathrm{n}=20)$ as depicted in Table 1 . Male form the greater number of respondents interviewed, it was observed that males in the selected communities were more interested in forest related issues and largely participated in previous management activities such as PAFORM project as well as the current Modified "Taungya" Systems in the reserve than the females. This is a positive indication for the implementation of the forest reserve management plan since the male are the heads of the family and can easily influence the rest of the family to rally behind the programme.

The majority of the respondents $(64.2 \%, \mathrm{n}=27)$ falls within the age range of $33-39$ years while $(21.4 \%, \mathrm{n}=$ 9) of the respondents were forty years plus. The other $(14.4 \%, n=6)$ falls within 18 - 32 years. This result simply shows that the youth who are more energetic and versatile are actively involved in the participatory approach. It also indicates that the youth in the selected communities are really concerned with restoration of the reserve. This is a good sign because it ensures the sustainability of the system or the management of the forest reserve. This ascertained a report by the PAFORM project on the selected communities who were engaged in Income

Table 1. Socioeconomic characteristics of the respondents.

\begin{tabular}{|c|c|c|}
\hline Variables & Frequency $(N=42)$ & $\%$ \\
\hline \multicolumn{3}{|l|}{ Gender } \\
\hline Male & 22 & 52.3 \\
\hline Female & 20 & 47.7 \\
\hline \multicolumn{3}{|l|}{ Age (years) } \\
\hline $18-25$ & 2 & 4.8 \\
\hline $26-32$ & 4 & 9.6 \\
\hline $33-39$ & 27 & 64.2 \\
\hline$>40$ & 9 & 21.4 \\
\hline \multicolumn{3}{|l|}{ Level of Education } \\
\hline Tertiary & 7 & 16.7 \\
\hline Senior High School & 8 & 19.0 \\
\hline Junior High School & 21 & 50 \\
\hline No formal education & 6 & 14.3 \\
\hline \multicolumn{3}{|l|}{ Occupation } \\
\hline Farming & 28 & 66.7 \\
\hline Trading & 8 & 19.0 \\
\hline Others $^{*}$ & 6 & 14.3 \\
\hline
\end{tabular}

Source: Fieldwork, 2014. "This means any job apart from trading and farming. 
Generation Activities along the Tain I forest reserve in January 2009; The youth of the selected communities had given strong backing to the decision by the Forestry Commission (FC) to prevent bush fires and illegal chain saw operations in the Tain I forest reserve.

The level of education of the respondents was $(50 \%, n=21)$ had Junior High school education, $(19 \%, n=8)$ had Senior High school education, and $(16.7 \%, n=7)$ had Tertiary education while $(14.3 \%, n=6)$ had no formal education. From the study, it was revealed that the higher percentage of the respondents were those that have had basic education but could not further for diverse reasons. The reasons for the inability of pursuing further education could be attributed or linked to illiterate parents asking their wards to quite school and help them on farm to feed the family. Others had to stop schooling because of inadequate funds to pursue high education. Very few felt bitter by their own doing because they stopped schooling for no apparent reasons but for delinquency. On the whole the illiteracy rate of the respondents, though low, was not too much of a problem because they could understand some policy statement and decision and then circulate the information to the community members.

The occupation of the respondents were $(66.7 \%, n=28)$ into farming, $(19 \%, n=8)$ into trading while $(14.3 \%$, $\mathrm{n}=6$ ) into varied types of occupation. Farming is the main source of livelihood in rural communities and this can clearly be seen in the result which shows the occupation of respondents. This result reveals that the communities' livelihoods are mostly on the forest and as such would be poor when prevented from having access to the forest resources.

\subsection{Forest Reserve Management Strategies Engaged in Tain Forest Reserve}

Table 2 identifies some reserve management strategies in managing Tain I forest in Sunyani Forest District. This shows the strategic management activities ongoing in sustainable management of Tain 1 Forest Reserve in Sunyani District of Forestry Commission.

From the data gathered as indicated in Table 2, 47.6\% strongly agreed that Tain I FR has a management plan and $11.9 \%$ also agreed. These two figures representing twenty-five of the respondents as majority claimed that they were part of the planning process when PAFORM project was undertaking the management planning exercise for Tain I between 2005-2009. However, 16.7\% representing seven respondents disagreed, 11.9\% representing five respondents strongly disagreed respectively claiming that they were not directly involved in the PAFORM project and cannot tell what went on at that time. The remaining $11.9 \%$ representing five respondents were neutral because they have no idea. It was generally accepted by the majority of the respondents that Forest Services Division (FSD) has a management plan that prescribes various strategies in managing Tain I forest reserve. However, the observation made from all the respondents point to the fact that they were not involved in the full implementation of these strategies. The few who were also initially engaged by PAFORM project in the formulation of the reserve management plan were left unattended too in one way or the other. This confirms (Blomley, 2013) who said that participating fully become difficult if it has no legal rights.

Table 2. Forest reserve management strategies.

\begin{tabular}{|c|c|c|c|c|c|}
\hline Variable & $\begin{array}{l}\text { Strongly } \\
\text { disagree }\end{array}$ & Disagree & Neutral & Agree & $\begin{array}{l}\text { Strongly } \\
\text { agree }\end{array}$ \\
\hline Tain 1 Forest Reserve has a management plan & $5(11.9 \%)$ & $7(16.7 \%)$ & $5(11.9 \%)$ & $5(11.9 \%)$ & $20(47.6 \%)$ \\
\hline $\begin{array}{l}\text { Forest Services Division (FSD) follow } \\
\text { the prescriptions in the management plan }\end{array}$ & $20(47.6 \%)$ & $10(23.8 \%)$ & $5(11.9 \%)$ & $2(4.8 \%)$ & $5(11.9 \%)$ \\
\hline $\begin{array}{l}\text { FSD contract boundary cleaning } \\
\text { involves other stakeholders }\end{array}$ & $30(71.4 \%)$ & $5(11.9 \%)$ & $2(4.8 \%)$ & $3(7.1 \%)$ & $2(4.8 \%)$ \\
\hline FSD involved FFCs in income generating activities & $3(7.1 \%)$ & $5(11.9 \%)$ & $2(4.8 \%)$ & $2(4.8 \%)$ & $30(71.4 \%)$ \\
\hline FSD has involved FFCs in modified taungya system & $30(71.4 \%)$ & $5(11.9 \%)$ & $5(11.9 \%)$ & $2(4.8 \%)$ & - \\
\hline $\begin{array}{l}\text { Private plantation establishment is } \\
\text { on-going in Tain } 1 \text { Forest Reserve }\end{array}$ & - & $2(4.8 \%)$ & - & $5(11.9 \%)$ & $35(83.3 \%)$ \\
\hline $\begin{array}{l}\text { FSD is now harvesting the matured teak } \\
\text { stands in the Tain } 1 \text { Forest Reserve }\end{array}$ & - & - & $2(4.8 \%)$ & $5(11.9 \%)$ & $35(83.3 \%)$ \\
\hline
\end{tabular}

Source: Fieldwork, 2014. 
The respondents were asked whether FSD is following the prescription outlined in the management plan in managing the reserve, twenty of the respondents representing $47.6 \%$ strongly disagreed; ten also representing 23.8\% disagreed forming generally disagreement of the majority that FSD is not using the expected prescription in the management of the forest reserve. Five of them, representing $11.9 \%$ strongly agreed and same number also were neutral while the remaining two of them representing $4.8 \%$ agreed with the view that three private companies who established teak plantations in the reserve are now doing harvesting (thinning) of their matured stands. They therefore claimed that this ongoing harvesting by the companies and maintenance of some few Modified "Taungya” Stands by few FFC members are some of the management descriptions in the management plan. This is diverse and difficult to conclude as the FFC lacked adequate information hence the fears of Kotey et al. (1998). This is in disagreement with (Kotey et al., 1998) they recommends a better participation and involvement of FFC's.

Again the data from the Table 2 revealed that thirty respondents representing $71.4 \%$ strongly disagreed; five of them representing $11.9 \%$ disagreed forming the majority who were not happy because FSD initially engage them in the boundary cleaning but later abandoned them making most of the boundaries left unattended. However, three (strongly disagreed) and two (disagreed) respondents representing $7.1 \%$ and $4.8 \%$ respectively were in general disagreement because they have no relationship with FSD and the remaining two representing seems to have no idea about the boundary contract cleaning. Though the previous knowledge of those who took part in 2004-2009 PAFORM projects is critical here but it was the duty of FSD to have educated FFC's of the project from its initiation to its completion. The community forestry management unit failed the FFC's as a regulator hence they evidence from respondents that they were abandoned. This was in disagreement with Brown (2000) who suggested that once the stakeholders have been identified, equitable partnerships must be established, so that all stakeholders feel comfortable with their roles in the project design process to empower the resource user groups and the rural organizations within which they are incorporated.

Respondents were further asked whether they were involved in the Tain I FR, thirty respondents strongly agreed representing $71.4 \%$ as the majority. This high response was because the respondents said they were part of the community group members assisted to engage in some IGAs by PAFORM project one way or the other. Unfortunately these activities were no longer in existence because when the PAFORM project exited their relationship with FSD was no more cordial when their contact persons on the project (CFs) were laid off. More so, three of them strongly disagreed and five disagreed representing $7.1 \%$ and $11.9 \%$ respectively were in general disagreement because they were not directly engaged in the PAFORM project let alone have no relationship with FSD and the remaining two representing 4.8\% have no idea about the IGA. More so the Income Generation Activities (IGAs) initiated at the time were all got burnt. For example, about 14.4 ha citrus and grafted mangoes inter cropped with pineapples established as IGAs for their livelihoods in the buffer zone.

Also, the respondents maintained that FSD has once engaged them on MTS and they have some shares in the stands that were established hence their continuous maintenance. Thus thirty-five of them representing $83.3 \%$ strongly agreed. Another 5 of them representing $11.9 \%$ disagreed as they have no link with the MTS and the remaining two representing $4.8 \%$ were neutral.

The respondents were further asked whether Forest Services Division (FSD) did engage private plantation developers in establishing any plantation in the reserve. Thirty five of the respondents, representing $83.3 \%$ strongly agreed that FSD engaged private plantation developers. Five of them, representing $11.9 \%$ agreed same and two of the respondents representing 4.8\% disagreed that FSD engaged private plantation developers. It also concludes that apart from FSD engaging some FFC members in the MTS other private plantation developers were also involved in establishing the plantation in the FR. The worse of it all was that the focal persons (Community Facilitators) for the project who were acting as liaison or extension officers between the FSD and the communities were also laid off when the PAFORM project exited. The consequences of these displeasures among the respondents led to the increase of bush fires and various forms of illegal activities in the forest reserve as most of them now became illegal chain operators and perpetrators of all forms illegalities in the reserve. Therefore for harmony to prevail in Tain I forest reserve sustainability, there must be transparency from the FSD and empowerment of the FFC which is in alignment with Fomete (2001) who suggested for the need of stronger legal institutions to entrench FFC's roles.

Finally, the respondents said that they observed that private plantation developers are now harvesting (thinning) the plantations established in the reserve. This was strongly agreed by thirty five of the respondents, representing $83.3 \%$, five of them, representing $11.9 \%$ agreed same and two of the respondents representing $4.8 \%$ 
did not know anything about it. It shows that indeed there is thinning operation on-going in the reserve. In this context, a range of factors may determine whether companies and communities strike up deals or actively avoid them. For companies, external policy or market duress to practice sustainable forest management may be important, as may economic considerations, such as the potential to cut costs, share risks or gain access to resources through engagement with local groups. Companies can provide skills, technologies, resources and access to markets that the community would otherwise be unable to obtain. There is the need to encourage partnerships and tackles the practical issue of how company community relationships can shift from raw deals to mutual gains. This is a good sign as FSD is looking at partnership with the relevant stakeholders as the way forward. This is in alignment with Asare (2001) who suggested that the FFC's must be granted local licensing and participates in revenue sharing in the forest reserve area. Still tend to define PFM in such areas, with limited local roles in overall decision-making as to the use and control of the resource.

\subsection{Stakeholders Participation in Forest Reserve Management}

Table 3 illustrates how Forest Fringe Communities participated in managing Tain 1 forest in Sunyani Forest District. This shows the Forest Fringe Community involvement and their roles needed to deliver a sustainable management of Tain 1 Forest Reserve in Sunyani Forest District of Forestry Commission.

From the data gathered as indicated in Table 3, 76.2\% of the respondents strongly disagreed and two of them also representing 4.8\% disagreed that FSD has involved them in Management of the Tain I FR which was not in line with government policy (Forest and Wildlife 1994 policy) which recognized that the local people could be more efficient at executing certain forest tasks. However, $7.1 \%$ of the respondents strongly agreed, $4.8 \%$ agreed to that and only $11.9 \%$ of them did not know that they were to be involved in management of the forest reserve. This concludes that FSD has not considered FFCs to play any role significantly to the Tain I forest reserve management. The Ghana forest and wildlife policy of 1994 acknowledges the fact that natural forest are being depleted day in and day out, and expresses concern for safeguarding the remaining natural forests for prosperity in order to conserve biodiversity, soil and water resources. Large parts of the natural forest are to be completely protected exclusively for conservation objectives. The policy emphasizes on the need to partner with local communities for the protection and management of forest resources. Notwithstanding the inputs of community forestry to sustainability, there is little investment accompanied policy declaration in terms of finances and manpower building of the FFC's by the government who depend heavily on external donor financing. The result is not in alignment with Brown (2000) and Asare (2001) who emphasized on empowerment and equity in terms of benefit sharing to the FFC's.

The respondents were asked whether Forest Services Division (FSD) did assign them any role in management of Tain I FR since the reserve is now degraded and being converted to plantation. Twenty of the respondents, representing $\mathbf{4 7 . 6 \%}$ strongly disagreed and ten respondents disagreed that FSD assigned them any role to

Table 3. Forest fringe community participation.

\begin{tabular}{|c|c|c|c|c|c|}
\hline Variable & $\begin{array}{l}\text { Strongly } \\
\text { disagree }\end{array}$ & Disagree & Neutral & Agree & $\begin{array}{l}\text { Strongly } \\
\text { agree }\end{array}$ \\
\hline FSD involved FFCs in managing Tain 1 Forest Reserve & $32(76.2 \%)$ & $2(4.8 \%)$ & $5(11.9 \%)$ & $3(7.1 \%)$ & - \\
\hline $\begin{array}{c}\text { FSD has assigned FFCs roles in managing } \\
\text { Tain } 1 \text { Forest Reserve }\end{array}$ & $20(47.6 \%)$ & $10(23.8 \%)$ & $5(11.9 \%)$ & $2(4.8 \%)$ & $5(11.9 \%)$ \\
\hline $\begin{array}{c}\text { FSD has involved FFCs as stakeholders in decision } \\
\text { making in formulation of Tain Forest } \\
\text { Reserve management planning }\end{array}$ & $2(4.8 \%)$ & 5 (11.9\%) & $2(4.8 \%)$ & $3(7.1 \%)$ & $30(71.4 \%)$ \\
\hline $\begin{array}{l}\text { FSD has involved FFCs in implementation of } \\
\text { Tain } 1 \text { Forest Reserve management plan }\end{array}$ & $30(71.4 \%)$ & 5 (11.9\%) & $5(11.9 \%)$ & $2(4.8 \%)$ & - \\
\hline $\begin{array}{c}\text { FFCs are involved in Benefit Sharing of proceeds } \\
\text { from Tain } 1 \text { Forest Reserve }\end{array}$ & $35(83.3 \%)$ & $2(4.8 \%)$ & $5(11.9 \%)$ & - & - \\
\hline $\begin{array}{l}\text { FSD involved FFCs in monitoring of activities } \\
\text { on going in Tain } 1 \text { Forest Reserve }\end{array}$ & $35(83.3 \%)$ & $5(11.9 \%)$ & $2(4.8 \%)$ & - & - \\
\hline
\end{tabular}

Source: Fieldwork, 2014. 
play in managing the forest let alone engaging them for rehabilitation of the reserve into plantation but rather all that they knew was that FSD gave the reserve to private plantation developers some who did not even employed them. Five respondents representing $11.9 \%$ strongly agreed, and two of them representing $4.8 \%$ agreed to that and only $11.9 \%$ of them did not know that they were to be involved in management of the forest reserve. It also concludes that FSD did not consider the stakeholdership of the FFCs in the management of the reserve. Collaborative forest management is a bottom-up approach in which communities in and around forest reserves are actively involved in the management of their forest resources. Management therefore involves recognition of the need to integrate conservation and development; the legitimacy of the rights of the local people to secure their economic future and the value of seeking the active involvement of the local people in environmental care and management.

Respondents indicated that they had some interactions with FSD during the PAFORM project but they cannot tell whether their inputs were taken on board. This was strongly agreed by thirty of the respondents; representing $71.4 \%$ and three of the respondents agreed to the fact that they were directly involved in PAFORM project during the formulation of the management plan of Tain I. Five of them, representing 11.9\% disagreed that FSD involved them and two of the respondents representing $4.8 \%$ also strongly disagreed on the ground that they have no technical knowledge about the activities of FSD. However, two of the respondents, representing $4.8 \%$ did not know anything about forest reserve management planning. It means generally therefore that there is much awareness created among the FFCs about the formulation of the management plan. This implies that limited capacity and skills undermines the effectiveness, efficiency and equity of the FFC's. They should have been resources by the government through the Forestry Commission.

Respondents noted that FSD did not involve them in the full implementation of the Tain I management as thirty of the respondents representing $71.4 \%$ strongly disagreed and five of them representing $11.9 \%$ disagreed. Meanwhile five of the respondents representing $11.9 \%$ have no idea and the remaining two representing $4.8 \%$ rather agreed that they were involved in the implementation. The higher record of disagreement was because since the exit of the PAFORM project FSD never supported their IGAs (Citrus farm, Bee keeping, etc) and the already established ones were also got burnt. It means that the FFCs were left on their own unattended when PAFORM project handed over the management of the reserve to FSD Sunyani District. The study revealed in the negative when the majority of the respondents vehemently disagreed with their involvement in the management of the Tain I forest reserve as reflected in Table 3 where $76.2 \%$ of the respondents strongly disagreed in the management of the reserve. Also the majority of the respondents representing $47.6 \%$ strongly disagreed having assigned any specific roles in managing the reserve. $71.4 \%$ of the respondents expressed that they were not involved during the implementation of the management plan. The respondents' involvement in benefit sharing and monitoring of activities on going in the reserve were also in the negative recording 83.3\% in strong disagreement respectively. This can be attributed to the fact that Tain I forest reserve is managed solely by FSD.

Similarly, thirty five respondents representing $83.3 \%$ strongly disagreed together with other two respondents of (4.8\%) also disagreed that FFCs were involved in benefit sharing of any proceeds from Tain I FR. Ironically the remaining five respondents representing $11.9 \%$ did not know anything about the benefit sharing. This also concludes that there is no equity between FSD and the FFCs as the government policy did not give legal rights to the FFCs over the resources. As a consequence, FFC's involvement in forestry projects is less; at the most they are being used as labourers in planting or for boundary contract cleaning.

Finally, the respondents maintained that they were not involved in monitoring of any activity on going in the Tain I FR. This is confirmed by the high record of thirty five respondents representing $83.3 \%$ strongly disagreed and five of them representing 11.9\% disagreed their involvement. Whiles the remaining 2 representing $4.8 \%$ knew nothing about monitoring. The consequences therefore is the connivances and abetting of some FFCs in committing all forms of illegal activities such as illegal chain sawing, gallamsey (illegal small scale mining) illegal logging in the reserve.

However, for the high percentage (71.4\%) scored for decision making was as a result of PAFORM project initiative where these majorities of the respondents in affirmative were part of the people who were embraced in focus group discussion and road mapping for the writing of the management plan for the reserve. This also support the work of Kotey et al. (1998) that people participation therefore demands that forest fringe communities were involved in all decision concerning the management and development of their forest reserves, since that will give them a better understanding and commitment to the natural resource development and protection by them. The result agrees with FAO (2010) contention that community forestry exist when the local community in 
an area plays a significant role in land use decision-making and when the community is satisfied with its involvement and benefit from the management of the surrounding forest and its resources.

\subsection{Types of Livelihood Activities Involved by the Forest Fringe Communities in Tain I Forest Reserve Management}

Table 4 illustrates the type of livelihood activities engaged in managing Tain 1 forest in Sunyani Forest District. This shows the livelihood activities needed to deliver a sustainable management of Tain 1 Forest Reserve in Sunyani Forest District of Forestry Commission.

As indicated from the data gathered in Table 4, the respondents were asked whether FSD has established grafted mango as an income generating activity for their livelihood sustenance along the periphery of the forest reserve and thirty-two of them, representing (76.2\%) strongly disagreed; two of them representing $4.8 \%$ disagreed; five representing $11.9 \%$ have no idea and three respondents representing $7.1 \%$ agreed. The higher number of representation for the disagreement according to the respondents was because although PAFORM project involved them in planting some mangoes all got burnt when the project was handed over to FSD to manage.

Also, the respondent's response to citrus establishment along the periphery of the reserve by FSD for them, twenty respondents representing $47.6 \%$ strongly disagreed; ten of them representing $23.8 \%$ disagreed; five representing $11.9 \%$ were neutral; two of them representing $4.8 \%$ agreed and the remaining five of them strongly agreed. This conclusion is also in line with the earlier explanation of what has happened to the mango. Furthermore, the respondents showed that Non Timber Forest Products (NTFPs) collection was allowed anytime they are available. In this case thirty respondents representing $71.4 \%$ strongly agreed, ten of them also representing $23.8 \%$ agreed whilst the remaining two of the respondents representing $4.8 \%$ remained neutral that NTFPs collection was allow.

From Table 4, the six selected communities were observed in numerous livelihood activities such as grafted mango, pineapple, citrus farming; Mushroom cultivation; grass cutter rearing; soap making; improved animal husbandry; and Non-Timber Forest Products (NTFPs) collection as a collaborative effort to ensure the sustainable management of forest resources. Brown (2000) observed that collaboration is a two-way affair, which involves exchange of experience and knowledge in partnership between the local people and forestry. Undauntedly management is the working partnership between the local people and the government where the community

Table 4. Livelihood activities of FFC's.

\begin{tabular}{|c|c|c|c|c|c|}
\hline Variable & $\begin{array}{l}\text { Strongly } \\
\text { disagree }\end{array}$ & Disagree & Neutral & Agree & $\begin{array}{l}\text { Strongly } \\
\text { agree }\end{array}$ \\
\hline $\begin{array}{l}\text { Grafted mango established along the periphery of Tain } 1 \\
\text { by FSD for FFCs in and around Tain } 1 \text { Forest Reserve }\end{array}$ & $32(76.2 \%)$ & $2(4.8 \%)$ & $5(11.9 \%)$ & $3(7.1 \%)$ & - \\
\hline $\begin{array}{l}\text { Citrus established along the periphery of Tain } 1 \text { by FSD } \\
\text { for FFCs in and around Tain } 1 \text { Forest Reserve }\end{array}$ & $20(47.6 \%)$ & $10(23.8 \%)$ & $5(11.9 \%)$ & $2(4.8 \%)$ & $5(11.9 \%)$ \\
\hline $\begin{array}{l}\text { Pineapples are inter planted in grafted mangoes and } \\
\text { citrus along the periphery of Tain } 1 \text { Forest Reserve }\end{array}$ & $30(71.4 \%)$ & $5(11.9 \%)$ & $2(4.8 \%)$ & $3(7.1 \%)$ & $2(4.8 \%)$ \\
\hline $\begin{array}{l}\text { FSD has allowed FFCs to collect NTFPs in Tain } 1 \\
\text { Forest Reserve }\end{array}$ & - & - & $2(4.8 \%)$ & $10(23.8 \%)$ & $30(71.4 \%)$ \\
\hline $\begin{array}{l}\text { Mushroom farming established by FSD for FFCs in and } \\
\text { around Tain } 1 \text { Forest Reserve }\end{array}$ & $30(71.4 \%)$ & $5(11.9 \%)$ & $5(11.9 \%)$ & $2(4.8 \%)$ & - \\
\hline $\begin{array}{l}\text { Grasscutter rearing established by FSD for FFCs in and } \\
\text { around Tain } 1 \text { Forest Reserve }\end{array}$ & $30(71.4 \%)$ & $5(11.9 \%)$ & $2(4.8 \%)$ & $3(7.1 \%)$ & $2(4.8 \%)$ \\
\hline Soap making for FFCs women established by FSD & $32(76.2 \%)$ & $2(4.8 \%)$ & $5(11.9 \%)$ & $3(7.1 \%)$ & - \\
\hline $\begin{array}{l}\text { Improved Animal Husbandry established } \\
\text { for FFCs by FSD }\end{array}$ & $32(76.2 \%)$ & $2(4.8 \%)$ & $5(11.9 \%)$ & $3(7.1 \%)$ & - \\
\hline $\begin{array}{l}\text { Other livelihood activities needed to be established to } \\
\text { assist and to involve FFCs in sustainable management } \\
\text { in Tain } 1 \text { Forest Reserve }\end{array}$ & - & - & 2 (4.8\%) & - & 40 (95.2\%) \\
\hline
\end{tabular}

Source: Fieldwork, 2014. 
this observation was fathom by Kotey et al. (1998) they revealed that collaboration in the forest resource members need to come together as is used to yearly engage the forest, since the forest is more of theirs than the Forest Services Division (FSD).

The respondents were further asked whether mushroom farming was established. $71.4 \%$ of the respondents strongly disagreed, $11.9 \%$ of them disagreed, and $11.9 \%$ was neutral and $4.8 \%$ of them agreed that it was established. This shows that this activity has also collapsed after the PAFORM project like other activities established at the time. As to whether grasscutter rearing was established in their various communities, $71.4 \%$ of the respondents strongly disagreed, $11.9 \%$ disagreed while $4.8 \%$ was neutral; $7.1 \%$ agreed and $4.8 \%$ agreed. It is also concluded that the store is the same like other PAFORM project established initiatives.

The respondents expressed their views that soap making although was established by PAFORM project for the women in their communities it also collapsed finally that is where $76.2 \%$ strongly disagreed and $4.8 \%$ strongly disagreed. However, $7.1 \%$ agreed whilst $11.9 \%$ remained neutral. More to the point, the respondents were of the view that an improved animal husbandry was established also By PAFORM project, $72.6 \%$ of the respondents strongly disagreed and $4.8 \% \%$ of them also disagreed. $11.9 \%$ remained neutral and $4.8 \%$ agreed. This representation also indicates that this noble initiative collapsed as PAFORM project exited. Finally, the respondents had a view that other livelihood activity establishment involving them will go a long way in protecting the forest from all illegal activities hence $95.2 \%$ strongly agreed the need whilst $4.8 \%$ remained neutral.

From the study the various community emphasized weak collaboration with authorities most especially FSD which makes it difficult to communicate well about management issues to them. This is as a result of the fact that although these livelihood activities were initially initiated by PAFORM project was finally left unattended. Finally, in Table 4 it was observed that the majority of the respondents are in favour of the need for other Livelihood activities integration in sustainable management of Tain 1 FR involving FFCs. The result supports Blomley et al. (2009) assertion that the re-engineering and integration of livelihood activities for FFCs in sustainable forest management offers greater efficiency in resource utilization reduces risk and provides additional food and income.

\section{Conclusion and Recommendation}

Government's policy in protecting forest begun way back in the 1980s and various forms of strategic interventions and policy reformations are ongoing. However, the activities of illegal operators are affecting the rate of regeneration. For Forest Fringe Community members, the Tain I forest reserve is becoming grassy each passing day due to constant depletions and rampant bush burning. They were also well aware that further depletion of the forest would affect them negatively and is therefore resolved to help in the proper management of the FR through the involvement and regular consultation from the FSD.

The study recognizes that the willingness of the FFCs to help in the management of the FR was demonstrated highly in the sense that co-management interrelationship in any business in the supply chain perspective is an added advantage to the members for that business sustainability. There is therefore the need for a dynamic and continuous look at all policies, plans and strategies in sustainable management of forest reserve through a supply chain perspective spectacle hence the study recommends the following for implementation:

For Forestry Commission to integrate community forestry, this paper offers the following recommendations:

- The authorities (Forestry Commission) should try to win the hearts and minds of the FFCs by re-engaging the Community Facilitators (CF) or create an Extension Services Unit as Liaison officers between FSD and the FFCs as earlier initiated by PAFORM project in order to enhance cooperation for improvement of the FR.

- Community members should be empowered to play the role of co-managers of the FR and to arrest and cease Forest products from the illegal operators with a rewarding packages in cash or kind (visit to other African countries to experience community forest management projects).

- The community members should be supported with capital to expand or identify their non-farm integrated multipurpose livelihood activities and promote value chain market for them to reduce dependence on the FR.

- The Technical Officers (TOs)/Range Supervisors (RSs) must improve their interpersonal relationship with the FFCs.

- The study will also encourage that there should be regular visit and interaction between FSD and the FFCs as they are the strongest links in the supply chain for managing the natural resource so that they will feel more 
involved in the management of the FR. There is a lots of importance when FFCs and other interested stakeholders involvement are identified through supplying chain sustainability, and this can bring about Sustainable Forest Reserve Management base in the Forestry Commission.

\section{References}

Agyeman, V. K., Marfo, K. A., Kasanga, K. R., Danso, E., Asare, A. B., Yeboah, O. M., \& Agyeman, F. (2003). Revising the Taungya Plantation System: New Revenue-Sharing Proposals from Ghana. Unasylva, 212, 40-43.

Asare, A. (2000). Community Involvement in Forest Management: The Experience of the Forestry Services Division of Ghana. Kumasi: CFMU.

Asare, A. (2001). Overview of Community Forest Committee’s Concept. Paper presented on the Inauguration of Community Forest Committees by Rudeya. Kumasi: CFMU.

Blomley, T., \& Ramadhani, H. (2006). Going to Scale with Participatory Forest Management: Early Lessons from Tanzania. International Forestry Review, 8, 93-100. http://dx.doi.org/10.1505/ifor.8.1.93

Blomley, T., \& Franks, P. (2009). Making Participatory Forest Management Work for the Poor. A review of Tanzanian and Nepali Experiences with Recommendations for Policy Makers and Field-Level Practitioners. Copenhagen: CARE Denmark.

Blomley, T., Lukumbuzya, K., \& Brodnig, G. (2011). Participatory Forest Management and REDD+ in Tanzania. Washington, DC: World Bank.

Blomley, T. (2013). Lessons Learned from Community Forestry in Africa and Their Relevance for REDD+. USAID-Supported Forest Carbon, Markets and Communities (FCMC) Program, Washington, DC.

Brown, D. (2000). The Gambian-German Forestry Project. In D. Brown, M. Howes, K. Hussein, C. Longley, \& K. Swindell (Eds.), Participation in Practice: Case Studies from the Gambia (2002, pp. 147-189). London: Overseas Development Institute.

Community Forestry in Namibia (CFN) (2008). Forests for People. Visions, Facts and Figures. Frankfurt: BMZ/KfW Germany.

FAO (2010). Global Forest Resource Assessment Key Finding. Rome: FAO

Fomete, T. (2001). The Forestry Taxation System and the Involvement of Local Communities in Forest Management in Cameroon. ODI RDFM Paper No. 25b, London: ODI.

Kotey, E. N. A., Francois, J., Owusu, J. G. K., Yeboah, R., Amanor, K. S., \& Antwi, L. (1998). Falling into Place. Police That Work for Forests and People Series No. 4. London: International Institute for Environment and Development.

Ministry of Land and Forestry (1996). Forestry Development Master Plan (pp26) Accra. Ghana: MLF.

Sagoe, F. (2013). Community Based Groups Contribution to Forest Management in Ghana. Accra.

Wily, L., \& Mbaya, S. (2001). Land, People and Forests in Eastern \& Southern Africa at the Beginning of the 21st Century. The Impact of Land Relations of the Role of Communities in Forest Future. Nairobi: IUCN EARO. (Monograph)

World Bank (2002). A Revised Forest Strategy for the World Bank Group Washington DC. Washington, DC: World Bank. 